\title{
Urban forest management in small Ontario municipalities
}

\author{
by E. John Barker ${ }^{1}$ and W. Andy Kenney²
}

\begin{abstract}
Urban forestry has emerged as an important and timely discipline in an urbanizing world. The practice of urban forestry has focused mainly on large urban centres but urban forests in small municipalities provide the same benefits to the residents within and around them. Small municipalities face many challenges similar to those in urban centres but a lack of resources may worsen the negative effects on small municipalities. Urban forestry in Ontario is undertaken by municipalities with little involvement from upper-level governments. Thus, the effectiveness of urban forestry in Ontario is inconsistent and sporadic, with many small municipalities unable to manage urban forests optimally. Ontario's legislative framework governing urban forestry is critiqued and compared to the system employed in the United States. Recommendations are provided for action toward a centralized urban forestry program in Ontario.
\end{abstract}

Key words: urban forestry, small municipalities, legislation, urban forestry in the United States

\section{RÉSUMÉ}

La foresterie urbaine est devenue une discipline importante et d’actualité dans un monde urbanisé. La pratique de la foresterie urbaine sest concentrée principalement dans les grands centres urbains, mais les forêts urbaines retrouvées dans les petites localités apportent les mêmes bénéfices aux résidents de ces municipalités et de leurs alentours. Les petites localités font face à de nombreux défis similaires à ceux des centres urbains mais le manque de ressources pourrait aggraver les effets négatifs observables dans les petites localités. La foresterie urbaine en Ontario relève des municipalités sans implication notable de la part des instances supérieures. En conséquence, l'efficacité de la foresterie urbaine en Ontario est inégale et sporadique, plusieurs petites localités ne pouvant aménager leurs forêts urbaines de façon optimale. La cadre législatif de l'Ontario portant sur la foresterie urbaine est étudié et comparé au système utilisé aux États-Unis. Des recommandations sont présentées afin de mettre en place un programme centralisé de foresterie urbaine en Ontario.

Mots clés : foresterie urbaine, petites localités, législation, foresterie urbaine aux États-Unis

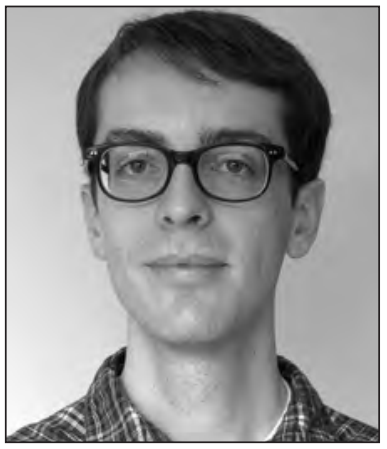

E. John Barker

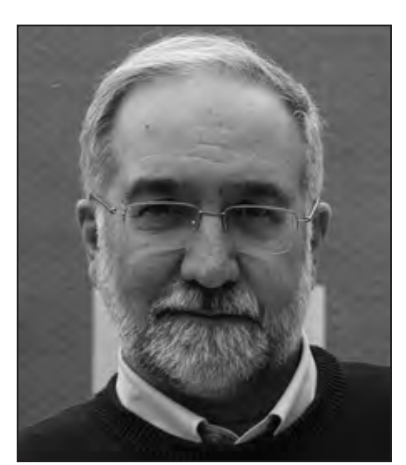

W. Andy Kenney

\section{Introduction}

Urban forests provide environmental, social, and economic services to the human populations living in their midst and improve urban quality of life (Dwyer et al. 1991, Nowak et al. 2001, Jackson 2003, McPherson et al. 2005, Rosen et al. 2006). While these services are naturally provided by urban forests, they are maximized by the long-term strategic planning and stewardship activities undertaken by urban forestry

practitioners. The corresponding effects on society can be substantial. Urban forests constitute the primary form of contact with all forest ecosystems for North American urban dwellers and as such may become the most influential forests of this century (Nowak et al. 2001). The Canadian Council of Forest Ministers (CCFM) acknowledges urban forests and urban forest stakeholders as integral components of Canada's future forestry sector (CCFM 2008). The impetus to conserve and properly manage urban forests is therefore urgent and highly necessary. Public education is an integral component of conservation efforts because of the large proportion of urban forest that is controlled by private ownership, which can account for up to $90 \%$ of a municipality's urban forest (Kenney and Idziak 2000).

While urban forestry's profile has recently grown, attention has focused mainly on large urban centres (Groninger et al. 2002). As a result, urban forests in small municipalities are comparatively poorly managed, although small municipalities could access the same benefits as urban centres and the cumulative impact of their urban forests could be significant (van Wassenaer et al. 2000). Development pressures and changing urban boundaries in small municipalities have forced a reconsideration of what is "urban" and hence, what is

\footnotetext{
${ }^{1}$ Master of Forest Conservation, Faculty of Forestry, University of Toronto, 33 Willcocks St., Toronto, Ontario M5S 3B3. E-mail: ejohn.barker@utoronto.ca

${ }^{2}$ Senior Lecturer, Faculty of Forestry, University of Toronto, 33 Willcocks St., Toronto, Ontario M5S 3B3. E-mail: a.kenney@utoronto.ca
} 
urban forest (Konijnendijk et al. 2006). Previous papers have called for a centralized urban forestry program to address the changing nature of urban environments and optimize management standards (CUFN 2010, Kenney 2003).

In Ontario, municipal governments are responsible for urban forestry, but official capacity is merely one of many factors that influence effective management. A network of relationships, resources, and environmental factors defines urban forests, but urban forestry overall is implemented in an inconsistent manner without significant involvement from a central guiding entity (Kenney 2003). Comparatively, the United States Department of Agriculture's (USDA) Urban and Community Forestry section operates at the federal level, with each state delivering programming. A similar model in Ontario could deliver resources to municipalities better than a de-centralized urban forestry sector, but each municipality's unique needs must be recognized.

\section{Urban Forestry in Small Municipalities}

Small municipalities face similar urban forestry challenges to those in large urban centres, including invasive pests, the effects of climate change, and budgetary constraints (Rosen et al. 2006). Operational success may be affected by the availability of information, the level of local expertise, population size, and community engagement in urban forestry (Grado et al. 2006). It can be difficult, if not impossible, for small municipalities to meet these challenges with their own resources and additional costs may be incurred due to poor or non-existent urban forest management strategies.

Urban forests can be vulnerable to many natural and human-induced effects that reduce their vitality and increase costs for municipalities. Inadequate resources often compel small municipalities to manage urban forests reactively, thus addressing problems as they arise rather than resolving them pre-emptively (Groninger et al. 2002). Serious implications for public safety can result, as hazardous trees can injure pedestrians, for which municipalities could be held liable and thus incur significant legal and compensatory costs. A strategic urban forestry framework may be created in response to an event that damages or deteriorates a community's urban forest (Kenney and Idziak 2000). While this approach may lead to improvements, it comes about only after significant value has already been lost and cannot substitute for proactive and preventive strategies. Consistent monitoring is integral to the safety and vitality of a community's urban forest, but many small municipalities cannot commit a continuous flow of financial and human resources (Maco and McPherson 2003). Unlike sample inventories, an inventory that is consistently updated allows urban forest managers to detect problems and manage proactively. The central principle guiding such adaptive approaches as that outlined in Kenney et al. (2011) is an integrated, strategic, and forward-thinking tactic that transcends operational activities and considers the full magnitude of the urban forest's impacts.

Urban forests with poor species richness are especially at risk from the effects of climate change because they lack the natural buffers against change that exist in diverse forests (Raupp et al. 2006). Furthermore, the environmental stresses of urban areas can weaken trees' defences against pathogens and pests (Raupp et al. 2006, CUFN 2010). Maintaining a diversity of species and age classes in an urban forest helps to safeguard against pests and may also increase overall biodiversity by providing habitat for urban biota.

Urbanization poses a challenge to small municipalities' urban forests that is not necessarily a concern within urban centres. While very little undeveloped land may exist in urban centres, small municipalities with growing populations must satisfy demand for expanding development (van Wassenaer et al. 2000). The resulting loss of urban forest benefits may extend beyond municipal borders and affect people living in nearby areas (Konijnendijk et al. 2004). Human encroachment, including waste disposal and yard extension, may exacerbate development pressures and degrade urban forests, negatively impacting biodiversity, soil stability, vegetation and corresponding benefits (McWilliam et al. 2010). Human encroachment can also increase fragmentation, alter forest ecosystem processes, and introduce invasive pests and fire to nearby intact forests (Nowak et al. 2005). By-laws, monitoring, and education are critical for urban forest protection, requiring adequate resources and skilled personnel. Innovative technology, such as GIS, has become increasingly important for devising long-term strategies, but its use is typically limited to larger urban centres (Groninger et al. 2002).

Small municipalities should be pursuing goals similar to larger urban centres, as the impacts of their urban forests affect their residents and those in surrounding areas. Official management approaches can be influential due to the municipality's status as the urban forest's primary managing entity. Yet, an integrated approach should involve community residents whose privately owned trees and shrubs generally constitute the majority of urban forests. In small municipalities, a relatively low population allows residents more opportunity for input, which can help to define the purpose of management activities and align management practices with residents' values. A well-informed local population would thus be a great asset to municipal urban forest planners in small municipalities.

Social and cultural factors can influence the development of urban forestry strategies. Urban forests take on different social significance according to cultural background or personal preferences, and values may change over time (Dwyer et al. 1991, Fraser and Kenney 2000). Management plans should recognize social values without losing sight of the strategic vision that guides long-term goals. Small municipalities can respond to the needs of changing communities by facilitating ongoing resident involvement, which can in turn broaden a municipality's set of skills and fill gaps in municipal resources (Nichnadowicz 2007).

Small municipalities face shortages of knowledge, expertise and resources that can negatively affect urban forest management. As a result, they tend to be more vulnerable than urban forests in larger urban centres. The sustainability of urban forestry requires coordinated stakeholder actions and an adaptive approach that embraces change and complexity (Dwyer et al. 2003). With open communication and a multistakeholder approach, urban forestry in small municipalities can contribute to the quality of life in and around those communities. This paper is intended to provide recommendations for improved urban forestry in small municipalities by assessing the possibilities for centralized urban forestry in Ontario. To this end, Ontario's legislative framework governing urban forestry practice and the USDA's urban forestry program are analyzed and compared. 


\section{Methodology}

Case study analysis and literature review methods were used to assess urban forestry in small municipalities. Information on case study municipalities was gathered through personal interviews with local urban forest practitioners and community stakeholders during the summer and fall of 2011. Scientific literature provided contextual and background information and was used to compare current management strategies to the ideal standard. Analysis of USDA Forest Service urban forestry programming was based upon evidence in peerreviewed literature and from USDA online sources.

The term "small municipality" was defined using Statistics Canada guidelines. Statistics Canada recognizes two types of urban centres, ${ }^{3}$ the smaller of which-Census Agglomerations-has a minimum core population of 10000 (Beshiri and He 2009). "Small municipality" refers to municipalities with a population between 1000 and 10000 and a population density of at least 400 persons per square kilometre. ${ }^{4}$ These include towns, villages, and amalgamated municipalities, providing the total amalgamated population conforms to the above parameters. As of 2006, approximately $5.6 \%$ of Ontario's population resided in these municipalities. ${ }^{5}$

\section{Case Studies}

The following case studies were selected to showcase the challenges and opportunities that exist in Ontario's small municipalities. In both cases, volunteers contribute valuable efforts to urban forestry projects by working to improve the municipality's standard of stewardship and providing advice to public and private stakeholders. Despite the interest in urban forestry that exists in some small municipalities, further assistance is required for optimal management.

\section{Case Study 1: Carleton Place, Ontario}

Carleton Place, Ontario, population 9453, (Statistics Canada 2007a) benefits from the Urban Forest/River Corridor Advisory Committee (UF/RCAC) comprised of local residents and professional urban forest practitioners. It was created to implement forest conservation and stewardship after the town's urban forest was damaged during the 1998 ice storm (Rosen et al. 2006). The committee coordinates planting programs in parks and on private land, while advising town council and departmental staff. In the latter role, committee members report concerns about urban forest conditions to municipal departments or staff. Committee members meet with and educate municipal staff about the value of urban trees and measures they can take to protect trees. In partnership with the municipality, the UF/RCAC promotes tree planting initiatives by planting trees with a high school environmental group and by distributing trees to residents at a subsidized cost (Jim McCready, Chair, Carleton Place Urban Forest/River Corridor Advisory Committee, personal com-

\footnotetext{
${ }_{3}^{3}$ Available from http://www12.statcan.ca/census-recensement/ 2006/ref/dict/tables/table-tableau-7-eng.cfm [Accessed October 31, 2011]

${ }^{4}$ Available from http://www.statcan.gc.ca/pub/21-601-m/2002061/ 4193597-eng.pdf [Accessed October 31, 2011]

${ }^{5}$ Ontario Ministry of Finance. Available from http://www. fin.gov.on.ca/en/economy/demographics/census/cenhi06-2.pdf [Accessed December 3, 2011]
}

munication, 2011). Carleton Place does not currently have a tree inventory due to a lack of resources, and as such, UF/RCAC conservation activities are planned and implemented at the discretion of its chair (Jim McCready, personal communication, 2011). While the involvement of an expert professional is valuable, overall programming would benefit from ongoing strategic initiatives like an inventory.

In light of urbanization pressures on urban forests, Carleton Place addresses development issues by requiring conservation plans for new development projects. These plans require developers to identify measures they will take to protect the environment surrounding the development, as well as plant and steward trees within the new development (Jim McCready, personal communication, 2011). These plans are subject to approval by an arborist and require the developer to replace trees that have been removed (Jim McCready, personal communication, 2011). Where feasible, several trees will be planted so as to replace as much of the lost leaf area as possible (Jim McCready, personal communication, 2011). Because Carleton Place does not have a tree by-law, trees removed from private property cannot be tracked.

\section{Case Study 2: West Perth, Ontario}

West Perth, Ontario, population 8839 , is an amalgamated municipality comprised of numerous communities, the largest of which is the town of Mitchell (Statistics Canada 2007b). Mitchell has conducted one complete tree inventory but is unable to update it and use its data due to a lack of resources (Don Giles, Chair, West Perth Forestry Committee, personal communication, 2011). West Perth lacks a longterm strategic vision for its urban forest and has no by-laws for individual tree protection, nor does it have a program to expand street tree plantings. These activities are hindered by shortages of funding and human resources (Ken Maronets, Stewardship Coordinator, Perth Stewardship Network, Ontario Ministry of Natural Resources, personal communication, 2011). However, West Perth has important initiatives that facilitate community involvement.

The West Perth Forestry Committee (WPFC) reports to council in an advisory capacity and spearheads several urban forest projects, including the Demonstration Forest and "For the Love of Trees" workshops. The former was established as a long-term tool to educate residents about local flora and selecting species to enhance local biodiversity (Don Giles, personal communication, 2011). "For the Love of Trees" workshops are held in the spring with the participation of tree specialists to educate residents about proper tree care (Don Giles, personal communication, 2011). Another committee runs the Memorial Forest, which helps residents plant trees in memory of loved ones (Don Giles, personal communication, 2011). West Perth's community projects rely heavily on volunteer involvement and sustained community interest. The West Perth Stewardship Network, a division of the Ontario Ministry of Natural Resources, is also involved in the municipality but their focus is largely on natural areas.

\section{Legislative Framework in Ontario}

Urban forestry policy in Ontario is fragmented and exists without significant involvement from federal or provincial governments (Kenney 2003). However, Ontario’s legislation recognizes that urban forestry is a unique and specialized 
field that manages a distinct type of forest ecosystem. This legislation does not eliminate provincial or federal government involvement that could improve and accelerate achievements currently underway. Ontario is currently the only province that explicitly identifies urban forestry in legislation. However, existing legislation does not invest significant authority in municipalities with respect to managing urban forests, but instead introduces minor piecemeal regulations.

\section{Professional Foresters Act}

The Professional Foresters Act defines the terms and regulations related to the professional practice of forestry in Ontario, including urban forestry. The act defines the urban forest as "tree-dominated vegetation and related features found within an urban area and includes woodlots, plantations, shade trees, fields in various stages of succession, wetland and riparian areas" (2000, c. 18 , s. 3 [3]). This definition leaves the definition of "urban" non-specific and acknowledges that while urban forests are unique ecosystems similar to natural forests, they assume various forms.

This act acknowledges urban forests in professional foresters' scope of practice, which is defined as "the provision of services in relation to the development, management, conservation and sustainability of forests and urban forests where those services require knowledge, training and experience ..." (2000, c. 18, s. 3 [1]). By identifying urban forests within this definition, the legislation acknowledges that urban forests, like natural forests, require specialized knowledge and management techniques. The act suggests that because professional urban foresters must be accredited, their work requires much more than simple street tree management. Activities included in the scope of practice applicable to urban forestry are appraisal and evaluation $(2000$, c. 18, s. 3 [1b]), assessment of the impacts of planned activities (2000, c. 18, s. 3 [1d]), and classification, inventory and mapping (2000, c. 18, s. 3 [1e])elements of urban forestry that should be integral to every strategic urban forest management plan. Small communities that lack qualified registered professionals may be unable to reap the rewards of this expert knowledge.

\section{Municipal Act}

The Municipal Act, 2001 (S.O. 2001, c. 25), defines the powers of municipal governments, including numerous provisions regarding urban forests. Municipalities may enact bylaws that "prohibit or regulate the destruction or injuring of trees" (2001, S.O. 2001, c. 25, s. 135 [1]), including public or private trees.

Through the use of tree conservation by-laws, upper- or lower-tier municipalities may institute tree protection in woodlots. The application of these powers is inconsistent across the province and depends largely on the resources each municipality is able to commit to their enforcement. The enactment of forest conservation by-laws at the upper-tier level does not guarantee that woodlots will be regulated in a small, lower-tier municipality, nor does it provide adequate conservation measures for the rest of the small municipality's urban forest. While by-laws could be useful tools for protecting urban trees, they are but one component of a comprehensive approach to urban forestry. The enactment and enforcement of by-laws are contingent on funding and political will. Small municipalities that enact tree conservation by-laws must shoulder the financial burden of enforcement while the benefits and services extend beyond their borders. Small municipalities may be among those least capable of codifying conservation practices into legislation, but the cumulative effects of poor management are significant beyond the municipal scale and demand comprehensive legislation.

\section{Planning Act}

The significance of the Planning Act (R.S.O. 1990, c. P. 13) for urban forestry is primarily in its application to land zoning, which is notable in light of development pressures and urbanization in small municipalities. The act is intended to promote "sustainable economic development in a healthy natural environment" (R.S.O. 1990, c. P. 13, 1.1[a]) and integrate "matters of provincial interest in provincial and municipal planning decisions" (R.S.O. 1990, c. P. 13, 1.1[c]). The act allows municipalities to develop official plans, which include provisions related to the natural environment (R.S.O. 1990, c. P. 13, 16 [1-2]). Zoning by-laws can restrict development activity carried out on certain areas of municipal land due to the presence of significant features.

A provincial policy statement on the Planning Act released by the Ministry of Municipal Affairs and Housing notes that the economic, ecological, and social benefits provided by natural features are determinants of long-term human wellbeing (MMAH 2005). The document offers some details on natural features, including significant wetlands, woodlands, valleys and wildlife habitat, which are to be protected from development and site alterations (MMAH 2005). A site's significance generally encompasses such values as ecological importance, functionality, economic importance and important habitat (MMAH 2005). The document does not mention street trees, which, as part of the urban ecosystem, are notable contributors to the well-being of communities.

The Municipal Act and the Planning Act contain provisions for municipalities that may relate to urban forest management but do not invest municipalities with the authority to comprehensively and consistently manage urban forests. The three acts discussed above acknowledge urban forests but do not elevate them to a position that requires legislative intervention to preserve their longevity and vitality. The cumulative impacts of poorly equipped municipalities demand that an overarching urban forestry strategy be designed and implemented for the benefit of all Ontarians.

\section{Urban Forestry in the United States}

The United States Department of Agriculture (USDA) administers the US Forest Service (USFS), which delivers Urban and Community Forestry (UCF) programs throughout the United States in a multi-stakeholder framework through state forestry agencies. ${ }^{6}$ The USFS has devised a cohesive and strategic plan for urban forests that addresses overarching priority issues. Informing the USFS's long-term vision is the awareness that most Americans live in close contact with urban forests and that urban forests constitute their primary experience with forests in general. The expansion of urban forestry programming and the involvement of the USFS with municipal governments have been linked to the

${ }^{6}$ USDA. Available from http://www.fs.fed.us/ucf/about_overview .html [Accessed November 8, 2011] 
Cooperative Forestry Assistance Act of 1978 (Konijnendijk et al. 2006). This legislation, updated in 2008, recognizes the declining condition of US urban forests, their ecological and social services, and the need for research and development (USDA 2011).

Despite its intentions, the UCF program has not benefited all municipalities equally. Numerous studies have used surveys of urban forest professionals and local practitioners to assess the level of engagement, quality of programming, resource allocation, and other factors related to state urban forestry programming. Small municipalities in Mississippi were found to be disproportionately lagging in their ability to fund and implement urban forestry projects, despite the existence of USDA resources (Grado et al. 2006). Larger municipalities, which had the highest response rate, were more familiar with urban forest management and funding opportunities (Grado et al. 2006).

Studies in Missouri (Treiman and Gartner 2004), Utah (Kuhns et al. 2005), and Massachusetts (Rines et al. 2011) found similar patterns, although local circumstances dictated a variety of attitudes and operational configurations. In Utah, for example, trees are not prominent in the natural landscape and therefore were often deemed less important (Kuhns et al. 2005). In Missouri, coordination between state authorities and municipal practitioners was not always a simple process as the local entities responsible for urban forestry were not always consistent (Treiman and Gartner 2004). Some municipalities conducted urban forest management through parks or public works departments, or there was no individual responsible for overseeing urban forestry (Treiman and Gartner 2004).

While Massachusetts is among the states with the highest proportion of its forests in urban areas (Nowak et al. 2001), Rines et al. (2011) found that only 15\% of responding communities managed their urban forests to the USFS's optimal standard. Responding municipalities were disproportionately those with larger populations and greater mean annual income, a phenomenon the authors attributed to multiple factors, including residents' level of education, political activity, citizen advocacy, and expectation of public services. A relatively low survey response rate on the part of small municipalities complicates an assessment of urban forestry conditions in small municipalities.

The USFS Urban and Community Forestry program delivers valuable resources and information to municipalities across the United States, but most urban forest management capabilities appear to remain with larger municipalities. There is an apparent lack of engagement with smaller municipalities, many of which are unaware of best management practices and the resources offered by state agencies.

\section{Conclusions and Recommendations}

Urban forests in small municipalities may be separated by abstract political boundaries, but they are part of a whole forested landscape and should be managed with a view to their cumulative impact using a multi-stakeholder approach. This requires the coordinated involvement and assistance of provincial or federal governments whose involvement must not obscure the ability of small municipalities to devise management strategies that are appropriate for local conditions. Provincial or federal government involvement should allevi- ate shortages in finances, human resources, technical capabilities, and expertise that plague many small municipalities.

The Ontario Ministry of Natural Resources (OMNR) is engaged in protecting natural heritage in Southern Ontario, among other tasks. ${ }^{7}$ The OMNR's partnerships with stakeholders, its development of geographic information, and its management of protected areas places it in a position to address the needs of urban forestry in Ontario, if allowed to develop a suitable program. This should entail a distinct urban forestry agency within OMNR, given the necessary specialization of techniques and knowledge. The inception of provincial urban forest programming should begin with an assessment of the current state of Ontario's urban forests and the needs of municipalities. This initial assessment would allow provincial planners to liaise with local actors and initiate the dialogue that would be necessary for future coordination and success.

The existence of a centralized urban forest program does not guarantee that small municipalities will be better equipped to meet urban forestry challenges. Adequately marketing a centralized urban forestry program to small municipalities would inform stakeholders of the resources available. The USFS's urban forestry programming outcomes demonstrate that small municipalities may continue to be disadvantaged if resources are not effectively shared. In order to avoid this problem, building interest and knowledge in small municipalities and the public should begin before the creation of centralized urban forest programming. Progress toward this goal may be achieved by multiple urban forest stakeholders, as summarized in Table 1. Larger municipalities could share their expertise and knowledge with small municipalities, thus empowering small municipalities to advocate the creation of centralized urban forestry programming and enable them to prioritize their concerns.

Community residents are crucial in elevating the quality of urban forestry in small municipalities, as well-informed residents can build interest through community projects and advocacy. The improvement of urban forestry in Ontario

\section{Table 1. Summary of recommended preliminary stakeholder} tasks.

\section{NGOs Municipalities Public}

Share information and expertise with small municipalities

Build interest in small municipalities

Educate and build interest in public

Lobby provincial and federal government for urban forest programming

$\bullet$

$\bullet$

70MNR. Available at: http://www.mnr.gov.on.ca/en/About/ index.html?CSB_ic-name=topMenu\&CSB_ic-info=about-us_Eng [Accessed November 12, 2011] 
must be achieved from above and from below, and it is clear that urban forestry education must occur on a large scale. The professional abilities of experts are valuable, but the public must want to protect its valuable community resources. Groups such as the Canadian Urban Forest Network and the Ontario Urban Forest Council are among many currently engaged in urban forestry education and a continuation of these efforts is necessary to promote the cause of developing comprehensive urban forestry programming. Their work would be enhanced by a centralized urban forestry agency whose provision of resources and expertise would enable communities to put educational material to practical use. Municipalities may also implement local urban forestry projects that raise public awareness about urban forestry. Efforts to lobby provincial and federal governments for the creation of urban forestry programming should come from all potential urban forestry stakeholders - the public, municipal governments, and non-governmental organizations. Thus, it should be demonstrably clear that urban forestry is an issue with political significance that requires the coordinated efforts of multiple stakeholders working to benefit the public and the environment.

\section{References}

Beshiri, R. and J. He. 2009. Immigrants in Canada: 2006. Rural and Small Town Canada Analysis Bulletin 8 (2). Ottawa: Statistics Canada, Catalogue no. 21-006-X. Available from http://www.statcan.gc.ca/pub/21-006-x/21-006-x2008002-eng.pdf [Accessed October 31, 2011].

[CCFM] Canadian Council of Forest Ministers. 2008. A Vision for Canada's Forests: 2008 and Beyond. 15 p. Available from http:// www.ccfm.org/pdf/Vision_EN.pdf [Accessed November 9, 2011].

[CUFN] Canadian Urban Forestry Network. 2010. October, 2010 draft: 2010-2015. Available from http://www.tcf-fca.ca/programs/ urbanforestry/cufn/resources/pages/files/OctoberFinal.pdf [Accessed October 25, 2011].

Dwyer, J.F., H.W. Schroeder and P.H. Gobster.1991.The significance of urban trees and forests: toward a deeper understanding of values. J. Arboric. 17: 276-284.

Dwyer, J.F., D.J. Nowak and M.H. Noble. 2003. Sustaining urban forests. J. Arboric. 29(1): 49-55.

Fraser, E.D.G. and W.A. Kenney. 2000. Cultural background and landscape history as factors affecting perceptions of the urban forest. J. Arboric. 26(2): 106-113.

Grado, S.C., D.L. Grebner, M.K. Measells and A.L. Husak. 2006. Status, needs, and knowledge levels of Mississippi's communities relative to urban forestry. Arboric. Urban For. 32(1): 24-32.

Groninger, J.W., D.D. Close and C.M. Basman. 2002. Can small, rural communities practice urban forestry? J. For. 100(1): 23-28.

Jackson, L.E. 2003. The relationship of urban design to human health and condition. Landsc. Urban Plan. 64: 191-200.

Kenney, W.A. 2003. A strategy for Canada's urban forests. For. Chron. 79(4): 785-789.

Kenney, W.A. and C. Idziak. 2000. The state of Canada's municipal forests - 1996 to 1998. For. Chron. 76(2): 231-234.

Kenney, W.A., P.J.E. van Wassenaer and A.L. Satel. 2011. Criteria and indicators for strategic urban forest planning and management. Arboric. Urban For. 37(3): 108-117.

Konijnendijk, C.C., S. Sadio, T.B. Randrup and J. Schipperijn. 2004. Urban and peri-urban forestry in a development context strategy and implementation. J. Arboric. 30 (5): 269-276.
Konijnendijk, C.C., R.M. Ricard, W.A. Kenney and T.B. Randrup. 2006. Defining urban forestry - a comparative perspective of North America and Europe. Urban For. Urban Green. 4: 93-103.

Kuhns, M.R., B. Lee and D.K. Reiter. 2005. Characteristics of urban forestry programs in Utah, US. J. Arboric. 31(6): 285-295.

Maco, S.E. and E.G. McPherson. 2003. A practical approach to assessing structure, function, and value of street tree populations in small communities. J. Arboric. 29(2): 84-97.

McPherson, G., J.R. Simpson, P.J. Peper, S.E. Maco and Q. Xiao. 2005. Municipal forest benefits and costs in five US cities. J. For. 103(8): 411-416.

McWilliam, W., P. Eagles, M. Seasons and R. Brown. 2010. Assessing the degradation effects of local residents on urban forests in Ontario, Canada. Arboric. Urban For. 36(6): 253-260.

[MMAH] Ministry of Municipal Affairs and Housing. 2005. Provincial Policy Statement. 37 p. Available from http://www. mah.gov.on.ca/Page1485.aspx [Accessed November 8, 2011].

Nichnadowicz, J. 2007. Community involvement in urban forestry programs. In J.E. Kuser (ed.). Urban and Community Forestry in the Northeast. pp. 147-163. Springer, New Brunswick, NJ.

Nowak, D.J., M.H. Noble, S.M. Sisinni and J.F. Dwyer. 2001.People and trees: Assessing the US urban forest resource. J. For. 99(3): $37-42$.

Nowak, D.J., J.T. Walton, J.F. Dwyer, L.G. Kaya and S. Myeong. 2005. The increasing influence of urban environments on US forest management. J. For. 103(8): 377-382.

Raupp, M.J., A. Buckelew Cumming and E.C. Raupp. 2006. Street tree diversity in Eastern North America and its potential for tree loss to exotic borers. Arboric. Urban For. 32(6): 297-304.

Rines, D., B. Kane, D.B. Kittredge, H.D.P. Ryan and B. Butler. 2011. Measuring urban forestry performance and demographic associations in Massachusetts, USA. Urban For. Urban Green. 10: 133-118.

Rosen, M., J. McCready and T. Bull. 2006. Raising the profile of Canada's $9^{\text {th }}$ forest region: Urban forests. For. Chron. 82(1): 54-56.

Statistics Canada. 2007a. Carleton Place, Ontario (Code3509028) (table). 2006 Community Profiles. 2006 Census. Statistics Canada Catalogue no. 92-591-XWE. Ottawa. Released March 13, 2007. Available from http://www12.statcan.ca/census-recensement/2006/ $\mathrm{dp}-\mathrm{pd} /$ prof/92-591/index.cfm?Lang=E [Accessed November 2, 2011].

Statistics Canada. 2007b. West Perth, Ontario (Code3531025) (table). 2006 Community Profiles. 2006 Census. Statistics Canada Catalogue no. 92-591-XWE. Ottawa. Released March 13, 2007. Available from http://www12.statcan.ca/census-recensement/2006/ dp-pd/prof/92-591/index.cfm?Lang=E [Accessed November 2, 2011].

Treiman, T. and J. Gartner. 2004. Community forestry in Missouri, U.S.: Attitudes and knowledge of local officials. J. Arboric. 30(4): 205-213.

[USDA] United States Department of Agriculture. 2011. Cooperative Forestry Assistance Act of 1978, as amended in 2008. In The Principle Laws Relating to USDA Forest Service State and Private Forestry Programs. pp. 1-38. Available at: http://www.fs.fed.us/ spf/coop/library/SPF-CF\%20handbook.pdf [Accessed November 8, 2011].

van Wassenaer, P.J.E., L. Schaeffer and W.A. Kenney. 2000. Strategic planning in urban forestry: A $21^{\text {st }}$ century paradigm shift for small town Canada. For. Chron. 76(2): 241-245. 